\title{
The Westerman Mound Site (41H015), Houston County, Texas
}

Timothy K. Perttula

Heritage Research Center, Stephen F. Austin State University

Follow this and additional works at: https://scholarworks.sfasu.edu/ita

Part of the American Material Culture Commons, Archaeological Anthropology Commons, Environmental Studies Commons, Other American Studies Commons, Other Arts and Humanities Commons, Other History of Art, Architecture, and Archaeology Commons, and the United States History Commons

Tell us how this article helped you.

This Article is brought to you for free and open access by the Center for Regional Heritage Research at SFA ScholarWorks. It has been accepted for inclusion in Index of Texas Archaeology: Open Access Gray Literature from the Lone Star State by an authorized editor of SFA ScholarWorks. For more information, please contact cdsscholarworks@sfasu.edu. 


\section{The Westerman Mound Site (41H015), Houston County, Texas \\ Creative Commons License \\ (c) $)(1)$ (9)}

This work is licensed under a Creative Commons Attribution-NonCommercial 4.0 International License 


\title{
The Westerman Mound Site (41HO15), Houston County, Texas
}

\author{
Timothy K. Perttula
}

\section{INTRODUCTION AND SITE SETTING}

The Westerman site is located in the middle Neches River basin in the Pineywoods of East Texas (Figure 1). The site, first recorded in 1969 (Kegley n.d.), is on an alluvial terrace lying between Armstrong Creek to the south and Cochino Bayou to the north (Figure 2a); these are eastward-flowing tributaries to the Neches River.

The site has a single earthen mound and an associated settlement that is estimated to cover ca. 10-15 acres; there are several areas at the site where aboriginal artifacts were noted at the surface (see Figure 2b; see

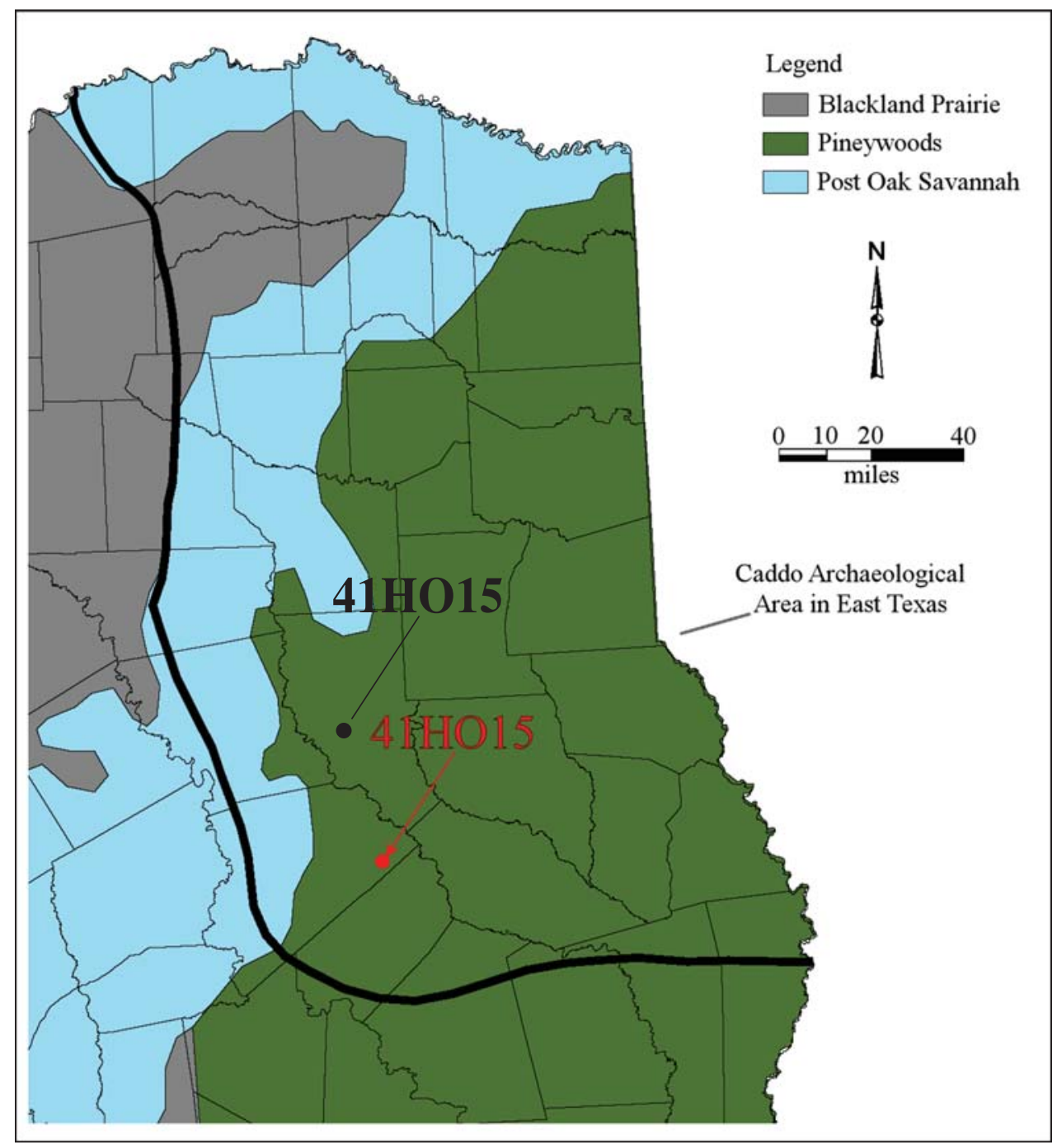

Figure 1. The location of the Westerman site in East Texas. 

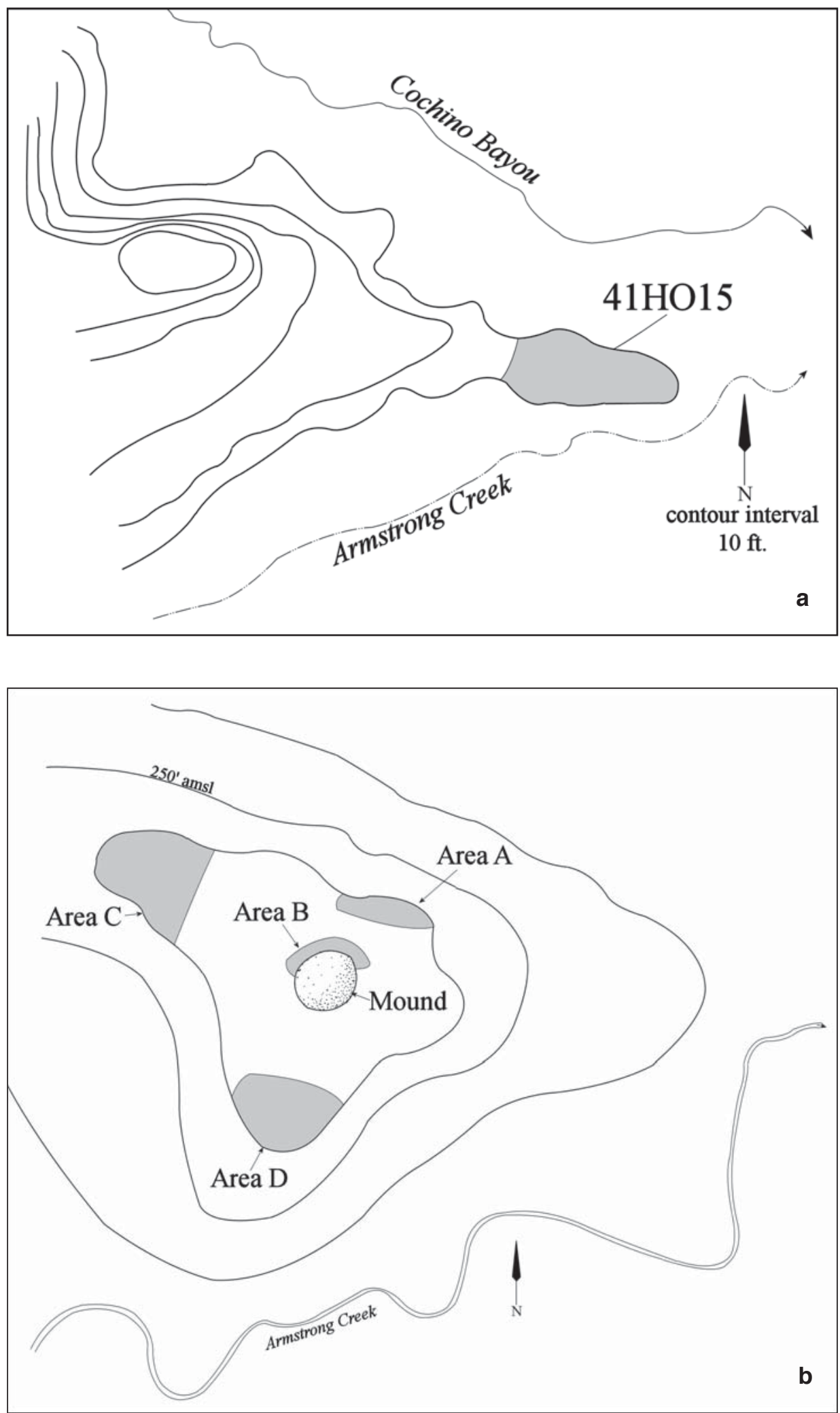

Figure 2. Setting of the Westerman site: a, broad scale; b, intra-site scale. 
also Martin et al. 1995:Figure 10), on each side of the mound. The mound, which was well preserved when it was visited in 1969, 1970, and 1986 by archaeologists from the Texas Archeological Research Laboratory at The University of Texas at Austin (TARL), is estimated to be $20 \times 25 \mathrm{~m}$ in size, rectangular-shaped, with a level top that covers a ca. $10 \times 5 \mathrm{~m}$ area; the height of the mound has not been established as it has never been mapped. The character of the archaeological deposits in the mound or the associated settlement has also not been established because no shovel tests or other forms of subsurface explorations have ever been conducted at the site. Only two small potholes were noted in the mound in 1969, and the mound and site were well preserved and protected by the landowners through the last visit by TARL personnel in 1986 .

TARL archaeologists had speculated that the mound may have been constructed during the Woodland period (between ca. 2500-1250 years B.P.); Woodland period mound sites are rare in East Texas. To investigate this possibility, or to establish that the mound may have been built by ancestral Caddo peoples native to East Texas, TARL had made plans to hold their annual field school at the Westerman site in both 1975 and 1976, with Dr. Dee Ann Story as the field school director. However, due to various circumstances, including sale of the property in April 1976, these field schools were unfortunately never held at the site. In 1986 Dr. Dee Ann Story and Janice A. Guy visited the Westerman site and completed a reconnaissance of the site to assess its current condition and obtain a surface collection of artifacts from the mound and associated settlement. The Westerman site does not appear to have been visited by professional archaeologists since that time.

\section{ARTIFACT ASSEMBLAGE}

Not including lithic debris, the artifact assemblage from several surface collections at the Westerman site includes ceramic sherds $(n=38)$, pieces of daub $(n=2)$, chipped stone tools $(n=16)$, and a fragment of a charred corn cob. The non-tabulated lithic debris includes pieces of local petrified wood and chert (earth-toned), as well as Manning Fused Glass (Brown 1976:Figure 3) likely from outcrops ca. $30 \mathrm{~km}$ south of the site.

\section{Ceramic Sherds}

Approximately 13 percent of the small ceramic sherd assemblage from the Westerman site are body sherds of Goose Creek Plain, var. unspecified (Table 1). Goose Creek Plain is a sandy paste ware that was made in Woodland period times in the southern part of East Texas (Ellis 2013:140-141 and Figure 1) by Mossy Grove Culture groups (Story 1990:Figure 39). These sandy paste sherds have been found in both Areas 1/A and 2/D, both north and south of the mound on the alluvial terrace (see Figure 2b).

Table 1. Ceramic sherds from surface collections at the Westerman site.

\begin{tabular}{lcccr}
\hline Type of Sherd & Area 1/A & Area 2/D & Area 3/B \\
Caddo wares & & & & \\
plain, grog-tempered & 3 & 18 & 2 & 23 \\
plain, bone-tempered & 2 & 1 & 1 & 4 \\
circular punctated, bone & - & 1 & - & 1 \\
fingernail punctated, bone & 1 & 1 & - & 2 \\
tool punctated, bone & - & 1 & - & 1 \\
Kiam Incised, grog & - & 1 & - & 1 \\
parallel incised, grog & - & 1 & & 1
\end{tabular}


Table 1. Ceramic sherds from surface collections at the Westerman site, cont.

\begin{tabular}{lccc}
\hline Type of Sherd & Area 1/A & Area 2/D & Area 3/B \\
\hline $\begin{array}{l}\text { Woodland period wares } \\
\text { Goose Creek Plain }\end{array}$ & 1 & 4 & - \\
\hline Totals & 7 & 28 & 3 \\
\hline
\end{tabular}

Note: this does not include five sherds from an undifferentiated surface location: one plain bone-tempered body sherd, a plain grog-tempered body sherd, a grog-tempered base sherd, a grog-tempered parallel incised body sherd, and a grogtempered fingernail punctated body sherd

The remainder of the ceramic sherds $(n=33)$ from known provenience are from grog-tempered $(n=25)$ and bone-tempered $(n=8)$ vessels; there are five other grog- or bone-tempered sherds from unknown provenience (see Table 1). The few decorated sherds in the assemblage include circular punctated $(n=1)$, fingernail punctated $(n=3)$, tool punctated $(n=1)$, and parallel incised $(n=2)$ decorative elements on body sherds from utility wares, as well as a Kiam Incised rim sherd from Area 2/D (Figure 3; see also Suhm and Jelks 1962:Plate 45a, d). This rim, with a direct profile and a rounded lip, has five horizontal incised lines on the rim itself, and a continuous series of vertical incised lines on the vessel body.

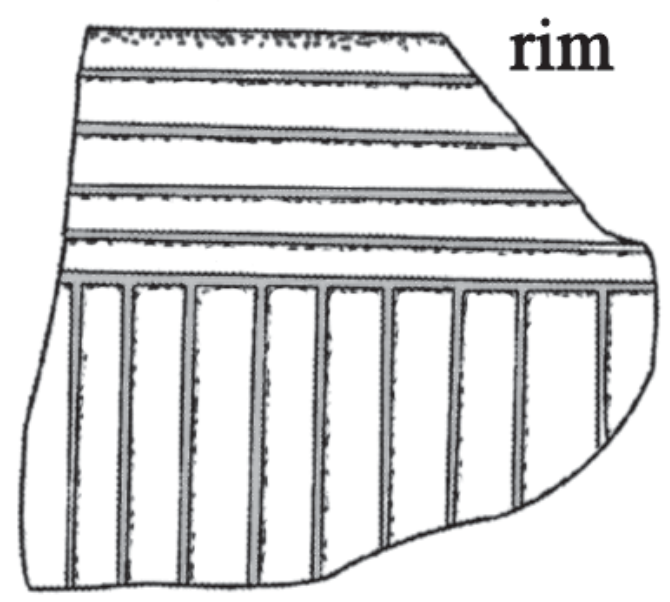

Figure 3. Kiam Incised rim sherd from Area 2 at the Westerman site.

\section{Daub}

Two large pieces of daub were collected from the surface of Area 2/Area D in March 1970. They came from the bank of Armstrong Creek southwest of the mound, in an area where daub was washing out of the creek bank and pieces of charcoal were noted in the creek bank profile. The daub and charcoal in this area strongly suggests that a burned grass-thatched structure was present in this part of the site, and was being eroded.

\section{Chipped Stone Tools}

The chipped stone tools are concentrated in Areas 1/A and Area 2/D at the Westerman site (Table 2), in areas on the alluvial terrace both to the north and south of the mound itself (see Figure 2b). Early Caddo 
arrow points of the Alba style (made from petrified wood and Manning Fused Glass) come only from the area in immediate proximity to the mound (and in fact may have come from back dirt on the mound itself; see Kegley n.d.); a pothunter had found another arrow point in his digging on the mound, but the type was not recorded by Kegley during his 1969 survey of the middle Neches River basin.

Table 2. Chipped stone tools from surface collections at the Westerman site.

\begin{tabular}{|c|c|c|c|c|c|}
\hline Tools & Area 1/A & Area 2/D & Area 3/B & Area $\mathrm{C}$ & $\mathrm{N}$ \\
\hline Alba AP & - & 1 & 1 & - & 2 \\
\hline Gary DP & - & - & - & 1 & 1 \\
\hline Trinity DP & - & 1 & - & - & 1 \\
\hline DP blade/tip & 1 & - & - & - & 1 \\
\hline end-side scraper & 1 & - & - & - & 1 \\
\hline side scraper & - & 1 & - & - & 1 \\
\hline flake tool & 1 & 1 & - & - & 2 \\
\hline gouge & 2 & 4 & - & - & 6 \\
\hline Biface, early stage & 1 & - & - & - & 1 \\
\hline Totals & 6 & 8 & 1 & 1 & 16 \\
\hline
\end{tabular}

$\mathrm{AP}=$ arrow point; $\mathrm{DP}=$ dart point

Note: this does not include one dart point (Wells, petrified wood) from an undifferentiated surface location.

There are four dart points from the site (see Table 2, including a Wells point from an unknown provenience), and their occurrence suggests use of the terrace during both Late Archaic and Woodland period times (see Turner et al. 2011). The one Gary point from Area $\mathrm{C}$ has a $13.2 \mathrm{~mm}$ stem width, suggesting it is a var. Camden point, and may date from ca. A.D. 200-700 (see Schambach 1982). The dart points are made from petrified wood $(n=3)$ and a non-local gray chert.

The scraping tools are on petrified wood (side scraper from Area 2/D) and a non-local dark gray chert (end-side scraper from Area 1/A). The flake tools and the unifacial gouges are made from local petrified wood, while the one early stage biface is made from a local fine-grained quartzite.

\section{Charred Maize Cob Fragments}

A single small charred corncob fragment was collected from the Westerman site during one of the surface collection efforts. The corn cob came from a low sandy rise about ca. $140 \mathrm{~m}$ west of the mound; it appears to have been displaced from archaeological deposits at this locale by rodent burrowing. It is not clear what cultural associations may exist between the mound deposits and the corn cob, or between the corn cob and the Caddo artifacts found at the site, but given the fact that all accepted radiocarbon dates on corn from East Texas sites postdate A.D. 900 and are exclusively from ancestral Caddo sites (Perttula et al. 2014), it seems reasonable to conclude that this single charred corn cob is from Caddo archaeological deposits preserved on this low rise west of the mound.

A small piece of the charred corn cob fragment was submitted to Direct AMS for radiocarbon dating. Calibrating the conventional radiocarbon age of $793 \pm 27$ years B.P. (D-AMS 007079) using OxCal v4.2.4, the charred corn cob fragment from the Westerman site has a 2 sigma calibrated age of A.D. 1205-1277 (94.5 percent probability) (Figure 4). The median calibrated age is A.D. 1242. 


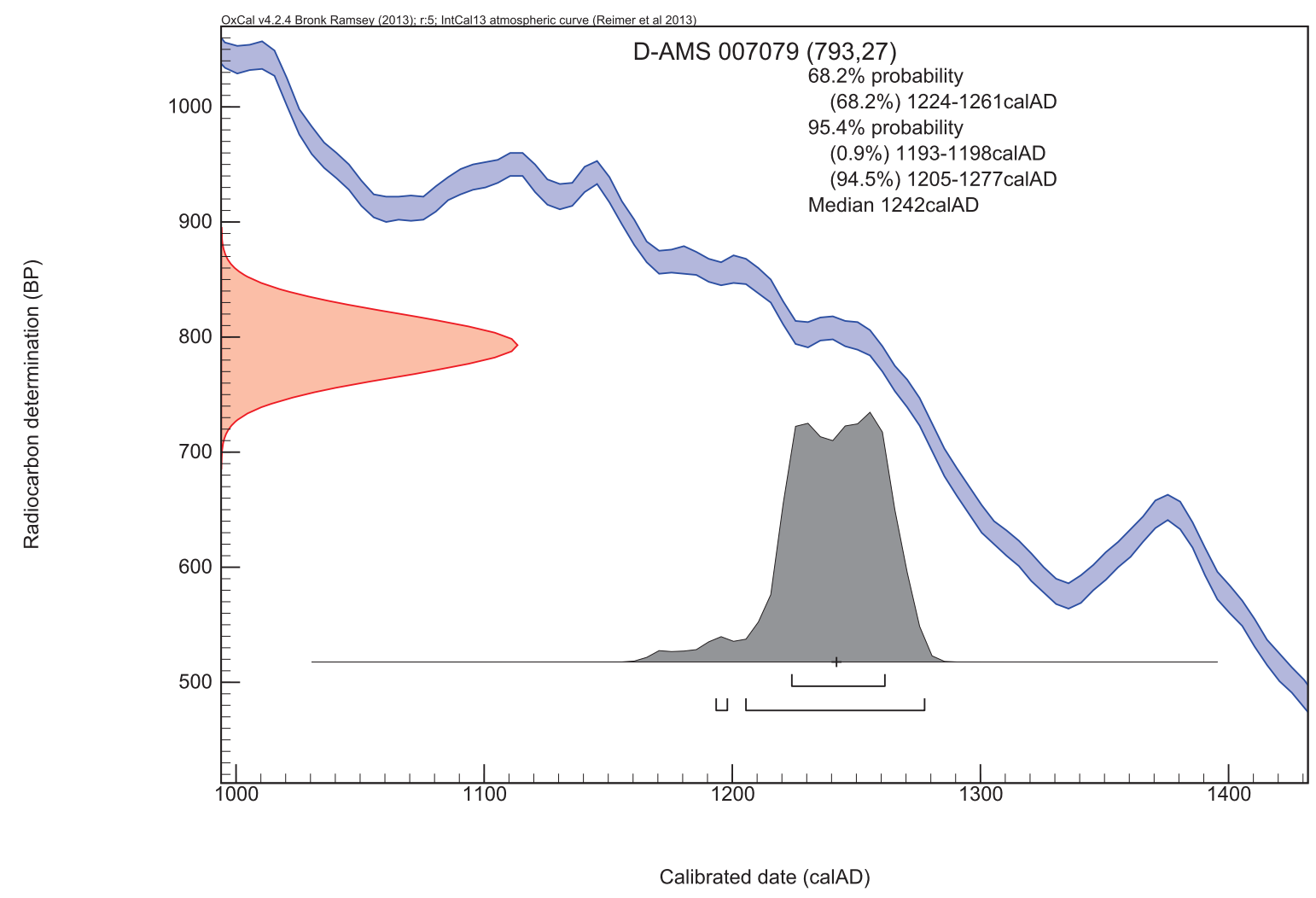

Figure 4. Calibration of radiocarbon date on the charred corn cob fragment from the Westerman site (41HO15).

\section{SUMMARY AND CONCLUSIONS}

The Westerman site is on an alluvial terrace of a tributary to the Neches River in the East Texas Pineywoods. The site has one small $(20 \times 25 \mathrm{~m})$ earthen mound and a 10-15 acre area of habitation debris that is likely associated with the construction and use of the mound. Since the mound and habitation areas have never been investigated by professional archaeologists, the age and function of the mound is not known, nor is it clear what the relationship is between the constructed mound and the habitation debris on the alluvial terrace.

The recovered artifacts from the site in the TARL collections are from surface collections only, from several areas around and near the mound. They indicate that the site was occupied to a limited extent during the Late Archaic period (marked by dart points and likely some of the chipped stone tools, including the petrified wood gouges), and also during the later part of the Woodland period, probably between ca. A.D. 200-700. This component is marked by a contracting stem Gary dart point and several Goose Creek Plain, var. unspecified sherds.

Although not substantial by any means, the most expansive habitation deposits - as well as an Alba arrow point from a pothole on the mound - at the Westerman site date to the Early Caddo period, from ca. A.D. 1000-1300, contemporaneous with the occupation at the George C. Davis site. These habitation deposits contain Alba arrow points, daub, and grog- and bone-tempered plain and utility wares, including a Kiam Incised jar rim sherd. A charred corn cob fragment from a habitation area at the site has a 2 sigma radiocarbon age range of A.D. 1205-1277. The Early Caddo period is likely when the mound was constructed and used at the Westerman site, which would indicate that it was occupied at the same time as the George C. Davis mound site and village, not far upstream on the Neches River (see Story 1997, 1998, 2000), and also used for both habitation as well as for religious and political rituals and ceremonies. 


\section{ACKNOWLEDGMENTS}

I would like to thank Jonathan Jarvis for facilitating the study of the collections and archival records from the Westerman site at the Texas Archeological Research Laboratory, The University of Texas at Austin. Lance Trask prepared the figures that accompany this article, and Robert Z. Selden Jr. provided the radiocarbon calibration of the date on the charred corn cob from the site.

\section{REFERENCES CITED}

Brown, K. M.

1976 Fused Volcanic Glass from the Manning Formation. Bulletin of the Texas Archeological Society 47:189207.

Ellis, L. W.

2013 Woodland Ceramics in East Texas and a Case Study of Mill Creek Culture Ceramics. Bulletin of the Texas Archeological Society 84:137-180.

Kegley, G. B.

n.d. An Archeological Survey of the Middle Neches. MS on file, Texas Archeological Research Laboratory, The University of Texas at Austin.

Martin, W. A., T. K. Perttula, N. A. Kenmotsu, L. Roark, J. Wise, J. E. Bruseth, J. Ippolito, V. Hubbard, and W. Kingsborough

1995 Cultural Resource Management Planning for the National Forests and Grasslands in Texas. Cultural Resource Management Report 6. Department of Antiquities Protection, Texas Historical Commission, Austin.

Perttula, T. K., R. Z. Selden, Jr., and D. Wilson

2014 Corn is Life: Temporal Trends in the Use of Corn (Zea mays) by Caddo Peoples from Radiocarbon-dated Samples and Stable Isotope Analysis. Bulletin of the Texas Archeological Society 85:159-181.

Schambach, F. F.

1982 An Outline of Fourche Maline Culture in Southwest Arkansas. In Arkansas Archeology in Review, edited by N. L. Trubowitz and M. D. Jeter, pp. 132-197. Research Series No. 15. Arkansas Archeological Survey, Fayetteville.

Story, D. A.

1990 Cultural History of the Native Americans. In The Archeology and Bioarcheology of the Gulf Coastal Plain, by D. A. Story, J. A Guy, B. A. Burnett, M. D. Freeman, J. C. Rose, D. G. Steele, B. W. Olive, and K. J. Reinhard, pp. 163-366. Research Series No. 38. 2 Vols. Arkansas Archeological Survey, Fayetteville.

1997 1968-1970 Archeological Investigations at the George C. Davis Site, Cherokee County, Texas. Bulletin of the Texas Archeological Society 68:1-113.

1998 The George C. Davis Site: Glimpses into Early Caddoan Symbolism and Ideology. In The Native History of the Caddo: Their Place in Southeastern Archeology and Ethnohistory, edited by T. K. Perttula and J. E. Bruseth, pp. 9-43. Studies in Archeology 30. Texas Archeological Research Laboratory The University of Texas at Austin.

2000 Introduction. In The George C. Davis Site, Cherokee County, Texas, by H. P. Newell and A. D. Krieger, pp. 1-31.2nd Edition. Society for American Archaeology, Washington, D.C.

Suhm, D. A. and E. B. Jelks (editors)

1962 Handbook of Texas Archeology: Type Descriptions. Special Publication No. 1, Texas Archeological Society, and Bulletin No. 4, Texas Memorial Museum, Austin. Reprinted in 2009, Gustav's Library, Davenport, Iowa. 
106 Journal of Northeast Texas Archaeology 52 (2015)

Turner, E. S., T. R. Hester, and R. L. McReynolds

2011 Stone Artifacts of Texas Indians. Taylor Trade Publishing, Lanham, Maryland. 